International Journal of Linguistics, Literature and Translation

ISSN: 2617-0299 (Online); ISSN: 2708-0099 (Print)

DOI: 10.32996/ijltt

Journal Homepage: www.al-kindipublisher.com/index.php/ijllt

\title{
Translation of Abbreviations in International Relations (IR)
}

\author{
Fatemeh Hosseinzadeh 8 (D) \\ Graduate student, Department of Translation Studies, Allameh Tabataba i University, Tehran, Iran
}

Corresponding Author: Fatemeh Hosseinzadeh, E-mail: hosseinzadeh.asal97@gmail.com

\section{ARTICLE INFORMATION ABSTRACT}

Received: August 08, 2021

Accepted: September 18, 2021

Volume: 4

Issue: 9

DOI: $10.32996 /$ ijllt.2021.4.9.13

\section{KEYWORDS}

Abbreviations, Acronyms, conventions, CDA, Discourse, Genre

\begin{abstract}
Abbreviation, as an old phenomenon in linguistics, is an inherent part of the technical texts and daily communications and as time goes on, making and using abbreviations is rapidly growing. The widespread usage of abbreviations has brought these linguistic formations into the field of translation. The present study aims to investigate differences in translation strategies of abbreviation when they appear in texts produced in different discourses and genres that need to be translated following social norms and conventions of the target language. To analyze abbreviations, their linguistic structures have been thoroughly discussed and they were analyzed according to the taxonomy proposed by Mattiello (2013). Fairclough's (1995) model of CDA has been adopted to show that translation, as it deals with language, is a social practice and social conventions and norms govern the translation strategies of abbreviations adopted by translators. In this regard, a corpus of 300 abbreviations was circulated. 150 abbreviations were collected from 5 translated books from English to Persian in the field of IR and their translation strategies were compared to 150 abbreviations that were translated in news texts concerning the same genre. The result indicated that while abbreviations in Persian scientific books were mostly borrowed, abbreviations in Persian news texts were translated by descriptive strategy. This implies that translation practice is inconsistent with the social norms and conventions of the target language society and it is the genre and discourse of the text that determines how a text must be translated.
\end{abstract}

\section{Introduction}

Abbreviation, a word-formation process in which words and phrases are shortened, is an old phenomenon and an inseparable part of the language. Although abbreviations are not new in languages, there is a strong disagreement among linguists about the structure of abbreviations and there is a lack of comprehensive study regarding their formations. Multiplication of abbreviations in language from technical texts to daily communications brings them into the sphere of translation and causes some challenges for translators to interpret these formations correctly and choose a proper strategy to translate them. Translators should consider many factors in choosing the strategy, from their types of formation and underlying phrases to social and conventional rules of the society that are in operation in producing a text. Thus, translators should pay attention to both micro and macro structures of a text in which abbreviations appear.

\section{Literature Review}

Although usage of abbreviation has been disseminated in the past two centuries, from a linguistic point of view is an old and universal phenomenon in linguistics that can be found in all languages, even dead ones (Zerkina \& Kostina \& pitina, 2015). Good examples are Greek manuscripts, Roman, Arabic and Old Persian. There were three types of abbreviations in Roman: Shortened form of words and syllables, Substitution of one letter with another and using "arbitrary signs" (Partington, 1838, p.5) and there are some abbreviations in the Quran, such as كهيعص (19:1), which are secrets of the Quran and no one can decode it. In Sassanid Empire, there were six words in Old Persian (e.g: DHYUV $\rightarrow$ DH) with eight abbreviated forms (Zahedi\& Sharifi, 1390, p.

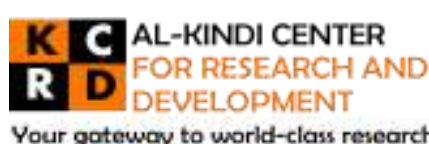

Your gateway to world-class research

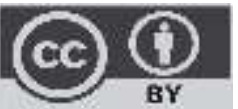

Published by Al-Kindi Center for Research and Development, London, United Kingdom. Copyright (c) the author(s). This open access article is distributed under a Creative Commons Attribution (CC-BY) 4.0 license 
39). These words were used only in written language due to the limitation of space in inscriptions, seals and coins (ibid). Also, in Hebrew, proper names were initialized, but these formations were not proliferated and recorded in dictionaries until the nineteenth century when there was a need for suitable technical terms and "advances in computer and technology" created the need for new concepts to refer to new devices (Mattiello, 2013, p. 64). Abbreviations were taken into account by lexicographers in 1873. In 1880, a collection of abbreviations, The Use and Abuse of Abbreviations by H. R. Boss, was published anonymously and Handbook of English Abbreviations written by Fallows was published in 1883 (Haymon, 1957). World Wars had a considerable role in the proliferation of military abbreviations in languages, especially in English, since these formations were used as codes among military forces to convey their messages safely. Abbreviations have proliferated in English more than other languages since it is grammatically flexible and its morphological structure is monosyllabic (Belda-Medina, 2001). Abbreviations are now part of the ordinary vocabulary of languages and the process is the result of the principle of economy in language and the principle of least effort which dominates all the linguistic aspects of utterances (Jam, 1395; Sharifi\& Zahedi, 1390).

Linguistically, an abbreviation is not, as some people consider it, 'damage of language' or artificially created structure; rather, it is, as Zerkina et al. state, a "regular process stipulated by changes" for communicating because of the development of the society (2015, pp. 137-8). In their paper, Zerkina et al. refer to the theory of equivalence which regards abbreviations as "lexical units that do not require any classification", but they themselves believe that these formations are not identical to words and they just "correlate with words" and needs to be classified (2015, p. 139).

In contrast to the proliferation of abbreviations in languages, their formation, compared to other word-formation processes, has received scant attention in the discipline and most of the investigations have focused on the product rather than arguing the process (Mattiello, 2013; Kriedler, 1979). Kriedler (1979) has pointed to this problem about thirty years ago, but the lack of comprehensive studies on abbreviation is still the main issue in linguistics. Another problem concerning abbreviations is that linguists rest these formations at which level of language. Some linguists categorize them as a type of word-formation processes, while others exclude them from such regular processes, reasoning that abbreviations "do not conform to canonical wordformation rules" and they are unpredictable (Mattiello, 2013, p. 97). Merchant (1969), considering word-formation processes as being morpheme-based, introduces abbreviations as one of "non-morphemic word-formation processes" and his argument is supported by Štekauer (1998) and Steinmetz and Kipfer (2006) (as cited in Fandrych, 2008). Fandrych herself accepts this viewpoint and mentions that the acronym is one of the non-morphemic word-formation processes and explains that in nonmorphemic word-formation processes, at least, there is an "element which is not a morpheme" (2008, p. 107). Mattiello (2013) describes abbreviations under the term extra-grammatical morphology rather than word-formation process. It is essential to elaborate on what she means by this term since, by classifying abbreviations as extra-grammatical, she introduces a new level to linguistics. She regards abbreviations as extra-grammatical structures since she believes that abbreviations are not regular, cannot be predicted and do not add a new meaning to their underlying phrases or words. Plag (2003) and Bat-El (2000) oppose these viewpoints and believe that abbreviation is a type of word-formation process since their patterns can be systematically analyzed and they are regular (as cited in Mattiello, 2013). Kreidler (1979) and Zerkina et al. (2015) are also among those linguists who consider abbreviations as part of word-formation processes.

Several divergent accounts of abbreviation and its classifications have been proposed, creating numerous controversies in linguistics. Al-Hamly \& Farghal (2013) name the whole process as English Reduced Lexical Forms (RFLs) and categorize them into three main types: abbreviations and acronyms, clipping and blending. They and Jam (1395) clarify that the pronunciation of abbreviations and acronyms differentiates them from one another. While abbreviations are pronounced letter by letter, acronyms are pronounced as words. This is how Jam (1395) classifies abbreviations. He, based on their pronunciations, divides them into two types: abbreviations and acronyms. Plag (2003) explains some other differences between acronyms and abbreviations (or initialisms): more constraints are at work in the formation of acronyms and only letters of initialisms are separated with dots, but Mattiello has found out that the tendency is to write initialisms without dots (p. 127, as cited in Mattiello, 2013). Kreidler (1979), naming the shortened forms as acronyms, explains that there are two types of acronyms: letterrecitation and letter-sounding. Letter-recitation acronyms are those which contain a letter from each major word of the underlying phrases. "The Letter-sounding type of acronym has to conform to the phonotactic norms of the language" (p. 25). Mattiello (2013) puts clippings and alphabetisms under the label abbreviation and alphabetisms include acronyms and initialisms.

There are various classifications of abbreviations in linguistics and the above-mentioned ones are a few of them which reveal linguists` divergent perspectives about these formations.

In this paper, abbreviations will be recognized and defined based on the extra-grammatical taxonomy proposed by Mattiello (2013). She takes the term abbreviation as an umbrella term for clipping and alphabetism. Alpahbetsim itself includes acronym and intialism. She thoroughly goes through her taxonomy in her book. 
Mattiello (2013) defines clipping as "a process which abbreviates a word to one of its parts, with a consequent loss of phonetic material" (p. 68). She believes that clipped words do not change semantically. She classifies clipping into four major types, i.e. fore-clipping, mid-clipping, edge-clipping and back-clipping. She also introduces two other types based on the addition of a suffix and randomly deleted letters.

1. Fore-clipping: "deletes the initial part of the word, thus preserving the final portion" (p.74). Examples are: sniff $\rightarrow$ niff, confess $\rightarrow$ fess, android $\rightarrow$ droid (Mattiello, 2013, p. 75).

2. Mid-clipping: "deletes the middle part of the word, thus preserving both extremities" (ibid). It is the rarest type of clipping and is unclear since the base word is not continuant in clipped form. E.g.: procurator $\rightarrow$ proctor, anorexia $\rightarrow$ ana (ibid)

3. Back-clipping: "deletes the final part of the word, thus preserving the initial portion" (p. 72). Dressler (2005) states that back-clipping is the most common one since it preserves the first part of the word which is the most transparent part of each word (as cited in Matteillo, 2013). Examples are fanatic $\rightarrow$ fan, talcum $\rightarrow$ talc, administrator $\rightarrow$ admin, holidays $\rightarrow$ hols, hyperactive $\rightarrow$ hyper, Promotion $\rightarrow$ promo,

4. Edge clipping: "deletes the initial and final portion of the word, thus preserving the medial portion" (p.75). influenza $\rightarrow$ flu, inquisitive $\rightarrow$ quiz (Stockwell and Minkova, 2001, p. 10, as cited in Mattiello, 2013).

5. Random clipping:"retains some scattred letters, specifically, consonants, from the base word (p.76): limited $\rightarrow$ Ltd, please $\rightarrow$ pls, people $\rightarrow$ ppl

6. Suffixed clipping: In some clipped words, one part is deleted and a suffix (-ie/-y, -o,-er/-ers) is substituted the omitted part. This type of clipping is common when there is a close relationship between speakers. aggravation/aggression $\rightarrow$ agro, barbecue $\rightarrow$ Barbie, Amanda $\rightarrow$ Mandy, , combination $\rightarrow$ combo, bedroom $\rightarrow$ bedder, collections $\rightarrow$ collekkers

Mattiello $(2013$, p. 76$)$ points another type of clipping, i.e. clipped compound but does not consider it as the main type of clipping, since in this type, the base word is a compound word, not a single one and it may cause a confusing similarity between clipping and blending.

According to Matiello (2013), alphabetism includes acronym and initialism and she defines acronyms and initialisms as words made by "initial letters of a phrase, title, compound or list" (p. 82).

She provides one definition for both, since distinguish a clear-cut boundary between acronyms and initialisms as two different structures. The main distinction between acronyms and initialism is that initialisms are pronounced letter by letter while acronyms are pronounced as full words (Mattiello, 2013). She further asserts that initialisms, like acronyms, can also be pronounced as full words if their formations conform to phonetic rules.

Since there is no clear-cut distinction between acronym and initialisms, Mattiello (2013) classifies both of them into almost similar types as they illustrate below:

1. Non-elliptic alphabetism: "retains the initial letters of all the words contained in the source phrase" (p. 87): REACT $\rightarrow$ Remote Electronically Activated Control Technology(acronym), URL $\rightarrow$ Uniform Resource Locator(initialism)

2. Elliptic alphabetism: "do not retain all the initial letters of the word contained in the source phrase" (ibid). Mainly the omitted letters belong to grammatical words (prepositions, conjunctions, articles and auxiliary verbs): PETA $\rightarrow$ people for the Ethical Treatment of Animals (acronym), MAE $\rightarrow$ Master of Arts in Education (initialism).

3. Extended alphabetism: "composed of more than one initial letter for each word" (p. 89). AMESLAN $\rightarrow$ American Sign Language.

4. Recursive Alphabetism: "one word of the source phrase coincides with the acronym itself" (p. ibid) . mung $\rightarrow$ mung until no good

5. Alphabetism with vowel addition: a vowel is added to alphabetisms in order to make them pronounceable. SLRF $\rightarrow$ Second Language Research Forum (it is pronounced as /slərf/).

6. Inverted letter alphbetism: the sequence of initial letters of the base word is changed. (MISHAP $\rightarrow$ Missiles High-Speed Assembly Program)

7. Semantically-irrelevant acrostics: acrostics whose orthoepic formations are unintentionally similar to an existing word, but they are not semantically related to that word (acrostics are 'acronyms whose reading/pronunciation coincides with a homophone word in the English language' (Conti and Mattiello, 2008, p. 563, as cited in Mattiello, 2013, p. 90)

SLEEP $\rightarrow$ Scanning Low Energy Electron Probe

8. Alphabetism with symbols, coordinators, prepositions or numerals

9. Semantically-relevant acrostics: " combinations that intentionally give rise to homophones" (p. 90) : BASIC $\rightarrow$ Beginners" all-purpose Symbolic Instruction Code 
Mattiello (2013) explains that both acronyms and initialisms can be elliptic, non-elliptic and semantically irrelevant, but only acronyms can be extended, recursive, inverted and semantically relevant.

As abbreviations have been proliferated in languages and are an inseparable part of any text, they need to be translated alongside all the verbal features of the texts. This is problematic since the translator, as the first step, needs to interpret them and their meaning may be ambiguous when the abbreviation denotes more than one underlying phrase. In such cases, the translator can decode them by noticing the text's genre or scientific area. The second step is to translate the underlying phrases of abbreviations into the target language and the third one is to choose a strategy to encode the abbreviations in the target language. The translator should decide whether to borrow them or try to form new abbreviations in the target text.

In many cases, the translation of abbreviations may not result in new formations (translation of UNESCO from English into Spanish) (Gonzalez, 1991).This happens mostly between languages that belong to the same proto-language (Al-Hamly\& Farghal, 2013). For instance, in the case of translating UNESCO into Spanish, both ST and TT are Indo-European languages and due to their similar alphabetical systems, translation results in abbreviations with alphabetically similar underlying phrases. But when it comes to languages with different origins, like Persian and Arabic, translating abbreviations from English into these languages may require a kind of coinage or other strategies.

Sometimes, the type of abbreviations can help the translator to choose the proper strategy. According to Gonzalez (1991), abbreviated names of international organizations that are widely known in the target language are generally translated, but when it comes to more specific terms, the abbreviations are borrowed to the target language.

Although translating abbreviations has become a crucial issue nowadays, little literature has been published on abbreviations' different translation strategies. Among those few articles is the work by Zerkina et al. (2015). They propose four strategies for translating abbreviations: "transference of foreign abbreviation with the equivalent abbreviation", "borrowing of a foreign abbreviation", "transliteration", "transcription" and "descriptive translation" (p. 553). It is important to mention that these strategies can be applied by considering different text features which abbreviations are to be translated as parts of it.

According to Fairclough (2016) 'texts are multi-functional', i.e., texts are "forms of actions", representative of things and presentation of identities (p. 187). The multi-functionality of texts is because they can be simultaneously analyzed at different levels. When it comes to translation, the translator needs to analyze these layers and functions to provide a translation that is not contradictory with the addressees' expectations and even target text social conventions. As for translating abbreviations, it is impossible to translate them out of their co-texts and contexts without analyzing the genre of the text and the properties of that genre in both source and target languages, since, without these considerations, the result will be unreadable or incomprehensible translations. Textual analysis will give the translator full awareness of the text properties to choose the proper strategy for translating abbreviations in the text. This means that macro-structures of the text determine translation strategies of the micro-structures, such as abbreviations.

In textual analysis, three functions, i.e. genres, discourses and styles, must be identified and connected to each other (Fairclough, 2016).

As was mentioned, in translating abbreviations, micro-structures (abbreviations) need to be seen as parts of macro-structures (texts), i.e., abbreviations are to be analyzed in texts they appeared in. Thus, a comprehensive model is required to enable the translators (or researchers) to analyze these macro-structures in order to provide acceptable translations of the texts. Critical discourse analysis (CDA), which analyses the language at the discourse level, could be one of the theories of language that can be applied in this sense.

Both linguists and social theorists use the term discourse in their analyses. In adapting the linguistic view of discourse, Fairclough defines it as "spoken or written language use" (1995, p. 92). He uses the term to view language as social practice and this view of language indicates that language, on the one hand, is an action and constitutes dimensions such as social identity and social relation on the other hand. What is crucial in critical discourse analysis (CDA), which has its root in critical theory of language, is that both sides of the language, i.e. being "socially shaped" and "constitutive" (ibid) must be taken into account and it should not be analyzed one-sidedly. So, in his viewpoint, texts are the results of discourse or language use as social practice; in other words, texts are produced under conditions of the society (Janks, 1997).

Fairclough calls the process of production or consumption of a text, discursive event or discursive practice and maintains that a discursive event, which is defined as an "instance of language use" (p. 95), is linked to the norms and conventions of the discourse. This implies that texts are produced in discursive events and their production is ruled or governed by the existing norms and conventions of the discourse and the linkage between discursive events and conventions, as a whole, is called orders 
of discourse. Thus, according to Fairclough (1995), a text is produced through a discursive practice and forms a discursive event which is linked to orders of discourse which itself is based on the rules and conventions of the society. This linkage is a logical reason for what is happened in the production of news texts in English and Persian. In English, the inclusion of abbreviations is a normal part of text production, since shortening is generally a conventional rule of language use (discourse), so it is normal to encounter abbreviations both in news texts and academic books. On the contrary, dealing with abbreviations in Persian news texts is unconventional since abbreviating phrases is not a conventional process in the Persian language and by doing so, the readers need to decode the abbreviations which is in contrast with the nature of the production of the news texts in websites, i.e., conveying information in a short time.

The relationship and boundary between norms and discursive events are complicated and discursive events are difficult to be categorized, since text production usually involves combining more than one type of discourse (Fairclough, 1995). Due to this complexity, Fairclough (1995) only differentiates between discourse and genre, i.e. "uses of language associated with a particular social activity" (p.96).

By CDA, Fairclough (1995) investigates the relationship between a text and its production (discursive practice) and social and cultural relations and conventions that affect the discursive practice. He considers this relationship obscure because the relationship between social structures, power relations, and discourse is not clear to those involved (Bourdieu, 1977, as cited in Fairclough, 1995).

To analyze this obscure relationship in discursive events, Fairclough (1995) proposes a "three-dimensional framework" (p. 94) in which any discursive event has three aspects: 1) text which is produced through 2) discursive practice which is part of 3) social practice, just like below:

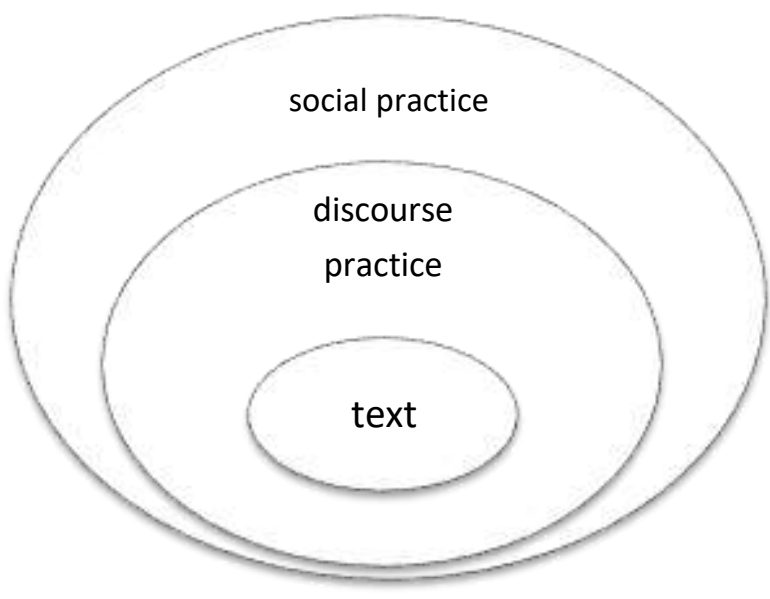

In this model, discourse practice is a mediator between a text and social practice (Fairclough, 1995).

In Fairclough's model of CDA, each of the three layers needs to be analyzed respectively. One begins with the text analysis to provide some assumptions about the social discourses that affect text production (Janks, 1997). Fairclough (1995) utilizes Halliday's model to analyze the first layer which is text. Analysis of discourse practice involves investigating "socio-cognitive aspects of text production and interpretation" and social practice is analyzed in terms of ideology, power relations and culture (p.94).

\section{Methodology}

The present study is a comparative applied type of research that delves into the differences in translation strategies of abbreviations in International Relations, as academic discipline and news texts. The corpus of this study is comprised of 150 abbreviations of each genre (total of 300). The researcher has tried to compile a corpus in which both genres are quantitatively equal in order to avoid any fluctuation in the comparison of strategies. As for collecting abbreviations of IR as discipline, five books, which were translated in the past twenty years, along with their source texts, were found in the digital library of Allameh Tabataba i University, Faculty of Law and Political Sciences (the years of translations were important, since it is not rational to compare outdated translations with newly translated news texts): 
سياست خارجى: نظريه ها، بازيخران و موارد مطالعاتى ، وير. اسميت استيو، اميليا هدفيلد، ترجمه : اميرمحمد حاجىيوسفى، محسن محمودى،

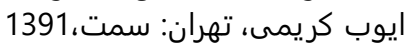

Smith, S. Hadfield, A. Dunne, T. Foreign Policy: Theories, Actors, Cases, $2^{\text {nd }}$ Ed.1990

آشوب در سياست جهان : نظريه اى در باره دگركونى و پييوستگى، جيمز روزنا؛ ترجمه: عليرضا طيب

F

Turbulence in World Politics: A Theory of Change and Continuity, N. Rosenau, James, 1990

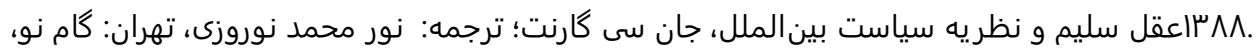

Commonsense and the Theory of International Politics , Garnett, John C, 1984

سازمان هاى بين المللى، فالكر ريتبركر، برنارد زنكل، ماتياس استاج؛ ترجمه: على بغيرى، تهران: دانشگاه امام صادق (ع)، 1389

International Relations: Polity, Politics and Policies; Rittberger, Volker, Bernad Zangl, Matthias Stiasch, 2006

محمد جعفر جواد، تهران: مهر،1379 دييلماسى نوين، آر بى بارستون؛ ترجمه:

Modern Diplomacy, R.P. Barston, 1988

Corpus of the news texts were collected in below websites:

English: Spuntiknews.com, newsweek.com, euronews.com, politico.com, edition.cnn.com, reuters.com, idpendent.co.uk

Persian: yjc.ir, farsnews.ir, mehrnews.ir, ir.sputniknews.com, tasnim.ir, farsi.euronews.com, m.dw.com

There were two procedures involved in this study, one for collecting abbreviations from the books and one for collecting abbreviations from the news texts. At first, the books were found in the library and were checked with their source texts to ensure they contained abbreviations. Then, the main texts of the books were compared with their sources and abbreviations were identified and listed based on the taxonomy provided by Mattiello (2013) (figures, tables, footnotes and other peripheral parts of the books are excluded in this study). Then, the strategies of translations were categorized and noted in front of each one. It should be noted that Zerkina et al. (2015) model of translation was not used as the framework, rather it was just used to name the processes and the researcher herself added omission to the strategies.

\section{Results and findings}

In the tables below, every strategy with its total percentage of occurance for the both type of text is listed:

Table No.1: translation strategies of abbreviations in scientific books:

\begin{tabular}{|l|c|}
\hline \multicolumn{1}{|c|}{ Strategy } & Percentage \\
\hline Descriptive translation & 31.3 \\
\hline Borrowing & 50 \\
\hline Transliteration & 6 \\
\hline Transcription & 5.3 \\
\hline Transference & 9.33 \\
\hline Omission & 2.6 \\
\hline
\end{tabular}

Table No.2: translation strategies of abbreviations in news texts:

\begin{tabular}{|l|c|}
\hline \multicolumn{1}{|c|}{ Strategy } & Percentage \\
\hline Descriptive translation & 51.3 \\
\hline Borrowing & 2.6 \\
\hline Transliteration & 5.3 \\
\hline Transcription & 2 \\
\hline Transference & 2.6 \\
\hline
\end{tabular}




\begin{tabular}{|l|c|}
\hline Omission & 25.3 \\
\hline
\end{tabular}

The study yielded the following findings: While in the Persian scientific books, the most applied strategy is borrowing, in news texts, it is a descriptive translation that dominates the translation of English news texts into Persian. After borrowing and descriptive translation, the highlighted point is the quantity of omission in these two genres. As with the news texts, about 25 percent of abbreviations were omitted during the process of translation, while in scientific books, it is the least used strategy with the percentage of 2.6. This is the order of discourse that determine the strategies in any genre and text. As with the scientific books, the order is that abbreviations are parts of the key concepts and needs to be rendered accurately. News texts may be omitted along with the other parts of the source text, since not all the information is to be translated into news texts. Only neseccary parts. The least used strategy in translation of abbreviations in news texts is a transcription with a percentage of 2 , because source language abbreviations are substituted with non-correlative abbreviations in this process and the appearance of abbreviations in news texts is contrary to the norms regarding the translation of news texts into the Persian language. After ommision and descriptive translation, transliteration is the most used strategy in the translation of news texts (eg. INSTEX is translated into اينستكس (إ). This strategy accelarets the process of translation, which is crucial in translating news texts because there is no need to find the underlying phrase in the process of translation. In scientific books, descriptive translation is the most used strategy after borrowing (31.3 percent compared to 50 percent). This happens because when abbreviations appear for the first time in the books, some of them are translated by descriptive strategy to let the reader comprehend them correctly for reading the rest of the books. These abbreviations are confusing or have more than one related underlying phrases. Transference strategy is used more in translation of scientific books (9.33 percent) than in the translation of news texts (2.6 percent), since Persian language have some technical abbreviations in the field of international relations that are equivalent to the source language abbreviations, but few abbreviations exist in news texts in Persian language to be equivalent to the souce language abbreviations. This study also shows that the process of translation is not detached from the analysis of style, discourse and genre that are interrelated. If translation is a social practice, then readers, as a part of society, are social agents whose views and expectations affects adopting strategies by translators. If we consider production and consumption of a text as discursive events, then two discursive events are at work in the process of translating a text containing abbreviations. One is consumption, in which the translator comprehends the abbreviations, and production, in which the translator chooses the proper strategy for translating abbreviations and it goes without saying that the norms and conventions of society govern discursive events. Thus, society's norms and conventions determine the proper strategy for translating abbreviations in scientific books and news texts based on their genres. This analysis reveals the fact that how a genre of the text can affect translators` decision-making.

\section{Conclusion}

The aim of this study was to investigate to what extent translation strategies of abbreviations are different when the texts belong to the same area with two different discourses. As was discussed before, Fairclough (1995) considers language as a social practice governed by society's norms and conventions. If language is a social practice, then translation directly related to language is a social practice. This means that translators are social agents who act as part of society and do their jobs according to the norms and conventions of society. This investigation was done to observe how much translations are affected by these norms. It is normal to deal with abbreviations in any genres and discourses in English since abbreviations are drastically proliferated in this language. Translating these formations into other languages is another story. Abbreviations have not been proliferated in all the languages as much as English. Moreover, in some languages such as Persian, it is not conventional to encounter a shortened phrase in all the areas and genres. One of these areas is news translation. While composing a news text containing abbreviation is normal, either to the writer or to the addressees, it is not conventional to encounter a news text bombarded with abbreviations, since the text will lose its goal, which is informative. This is because native speakers of English are familiar with abbreviations and do not need to decode the text, but native speakers of Persian have to spend some time decoding them. That is why most of the abbreviations in news texts are translated into Persian with a descriptive translation strategy. When it comes to the scientific case, the case is completely different, since the addressees of a translated scientific text are experts of their field and they are familiar with the terminology of the field, since most of their books and the concepts of their major have brought in the field through the process of translation. Thus, when the translator is to translate a scientific book, they mostly borrow the abbreviated forms since it is considered as a convenient way of translating a scientific book. 


\section{References}

[1] Al-Hamly, M. \& Fa (2013). English Reduced Forms in Arabic Scientific Translation: A Case. Jordan Journal of Modern Languages and Literature, 5(1), pp.1-18.

[2] Belda-Medina, J. (2001). Computer Terminology: Problems in Translating Abbreviations and Acronyms. First International Conference in Specialized Translation (pp. 67-69). Barcelona: Universitat Pompeu Fabra.

[3] Fairclough, I., \& Fairclough, N. (2016). Textual Analysis. In T. Analysis, Routledge Handbook of Interpretive Political Science (pp. 186-198). New York: Routledge.

[4] Fairclough, N. (1995). Critical Discourse Analysis and Marketisation of Public Discourse: The unversities. In N. Fairclough, Critical Discourse Analysis (pp. 91-125). New York: Routledge.

[5] Fandrych, I. (2008). Submorphemic Elements in the Formation of Acronyms, Blends and Clippings. Lexis, 103-121.

[6] Gonzalez, F. R. (1991). Translation and Borrwing of Acronyms and Abbreviations:Main Trends. International Review of Applied Linguistisc in Language Teaching, 29(2), 161-170.

[7] Haymon, S. (1957). The Short of It. Emerald Insight, 16(3), 165 - 169.

[8] Janks, H. (1997). Critical Discourse Analysis as a Research Tool. Discourse: Studies in the Cultural Politics of Education, 18(3), $329-342$.

[9] Kreidler, C. W. (1979). Creating New Words By Shortening. Journal of English Linguistics, 13(1), 24-36.

[10] Mattiello, E. (2013). Abbreviations. In E. Mattiello, Extra-grammatical Morhology in Linguiatics (pp. 64-109). Berlin: De Gruyter Mouton.

[11] Natalia Zerkina, N. K. (2015). Abbreviation Semantics. Procedia - Social and Behavioral Sciences, 199, 137 - 142.

[12] Partington, C. F. (Ed.). (1838). The British Cyclopaedia of the Arts, Sciences, History, Geography, Literature, Natural History, and Biography (Vol. 1). London: Wm. S. Orr and Company.

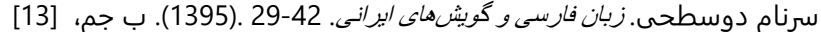

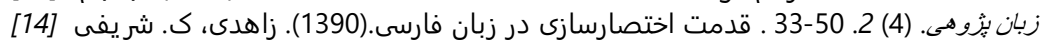

\section{Appendix}

Data collected from the scientific books:

\begin{tabular}{|c|c|c|c|}
\hline Abbreviation & Persian Equivalent & Type of abbreviation & Translation Strategy \\
\hline IR & روابط بينالملل & Non-elliptic initialism & Descriptive translation \\
\hline CFP & CFP & Non-elliptic initialism & Borrowing \\
\hline DDIR & داده & Non-elliptic initialism & Descriptive translation \\
\hline GUT & نظريه كلان يكيارجه & Non-elliptic initialism & Descriptive translation \\
\hline COPDAB & COPDAB & Non-elliptic initialism & Borrowing \\
\hline NSS & NSS & Non-elliptic initialism & Borrowing \\
\hline ANZUS & انزوس & Non-elliptic initialism & Transliteration \\
\hline JTC & ---- & Non-elliptic initialism & Omission \\
\hline WMD & WMD & Non-elliptic initialism & Borrowing \\
\hline OPEC & اويك & Non-elliptic initialism & Transliteration \\
\hline IRBM & موشك هاى قارهييما & Non-elliptic initialism & Descriptive translation \\
\hline MNC & MNC & Non-elliptic initialism & Borrowing \\
\hline EWAMS & EWAMS & Non-elliptic initialism & Borrowing \\
\hline CNN & CNN & Non-elliptic initialism & Borrowing \\
\hline FPA & FPA & Non-elliptic initialism & Borrowing \\
\hline
\end{tabular}




\begin{tabular}{|c|c|c|c|}
\hline WEIS & WEIS & Non-elliptic initialism & Borrowing \\
\hline FPA & تحليل سياست خارجى & Non-elliptic initialism & Descriptive translation \\
\hline ACP & ACP & Elliptic initialism & Borrowing \\
\hline GUTT & كات & Non-elliptic initialism & Transference \\
\hline OECD & OECD & Non-elliptic initialism & Borrowing \\
\hline IPC & IPC & Non-elliptic initialism & Borrowing \\
\hline NEIO & $\mathrm{NEIO}$ & Non-elliptic initialism & Borrowing \\
\hline UNCTAD & UNCTAD & Non-elliptic initialism & Borrowing \\
\hline GSP & GSP & Non-elliptic initialism & Borrowing \\
\hline USSR & معاهدهى منع آزمايش اتمى & Non-elliptic initialism & Descriptive translation \\
\hline ECDC & ECDC & Non-elliptic initialism & Borrowing \\
\hline ASEAN & آسه.آن & Non-elliptic initialism & Transliteration \\
\hline IMF & صندوق بينالمللى پيول & Non-elliptic initialism & Descriptive translation \\
\hline KEDS & KEDS & Non-elliptic initialism & Borrowing \\
\hline ITO & ITO & Non-elliptic initialism & Borrowing \\
\hline BIS & BIS & Non-elliptic initialism & Borrowing \\
\hline FPA & تحليل سياست خارجى & Non-elliptic initialism & Descriptive translation \\
\hline NATO & يِيمان آنتلانتيك شمالى & Non-elliptic initialism & Descriptive translation \\
\hline NATO & ناتو & Non-elliptic initialism & Transliteration \\
\hline NATO & ---- & Non-elliptic initialism & Omission \\
\hline ASW & كلاهك جند رِيكانهاى & Non-elliptic initialism & Descriptive translation \\
\hline MIRVs & موشك هاى ضد موشك & Non-elliptic initialism & Descriptive translation \\
\hline $\mathrm{ABM}$ & تسليحات ضد ماهوارهاى & Non-elliptic initialism & Descriptive translation \\
\hline DON & DON & Non-elliptic initialism & Borrowing \\
\hline FPDM & تصميم گيرى سياست خارجى & Non-elliptic initialism & Descriptive translation \\
\hline SOP & SOP & Non-elliptic initialism & Borrowing \\
\hline MBFR & MBFR & Non-elliptic initialism & Borrowing \\
\hline CFF & CFF & Non-elliptic initialism & Borrowing \\
\hline IMF & IMF & Non-elliptic initialism & Borrowing \\
\hline
\end{tabular}




\begin{tabular}{|c|c|c|c|}
\hline CSCE & كنفرانس امنيت و همكارى در & Non-elliptic initialism & Descriptive translation \\
\hline ECC & ECC & Non-elliptic initialism & Borrowing \\
\hline UN & UN & Non-elliptic initialism & Borrowing \\
\hline UNESCO & يونسكو & Non-elliptic initialism & Transliteration \\
\hline SALT & مذاكرات اعراب و اسرائيل & Non-elliptic initialism & Descriptive translation \\
\hline SDR & SDR & Non-elliptic initialism & Borrowing \\
\hline ONUC & ONUC & Non-elliptic initialism & Borrowing \\
\hline ENDC & ENDC & Non-elliptic initialism & Borrowing \\
\hline$C C D$ & كميته خلع سلاح & Non-elliptic initialism & Descriptive translation \\
\hline EFF & تسهيلات صندوق توسعه & Non-elliptic initialism & Descriptive translation \\
\hline CWS & معاهده منع سلاحهاى & Non-elliptic initialism & Descriptive translation \\
\hline EMU & ----- & Non-elliptic initialism & Omission \\
\hline ONUC & ماموريت كنكو & Non-elliptic initialism & Descriptive translation \\
\hline UNIMOG & UNIMOG & Non-elliptic initialism & Borrowing \\
\hline GDP & GDP & Non-elliptic initialism & Borrowing \\
\hline IAEA & IAEA & Non-elliptic initialism & Borrowing \\
\hline GEF & سازمان تسهيل جهانى محيط زيست & Non-elliptic initialism & Descriptive translation \\
\hline HIPC & HIPC & Non-elliptic initialism & Borrowing \\
\hline CFC & CFC & Non-elliptic initialism & Borrowing \\
\hline
\end{tabular}

\begin{tabular}{|c|c|c|c|}
\hline VERA & محدوديت هاى صادرات & Non-elliptic initialism & Descriptive translation \\
\hline VERS & VERS & Non-elliptic initialism & Borrowing \\
\hline RAND & رند & Non-elliptic initialism & Transcription \\
\hline IRA & ارتش آزادى بخش ايرلند & Non-elliptic initialism & Descriptive translation \\
\hline ETA & 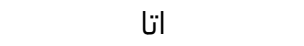 & Non-elliptic initialism & Transcription \\
\hline GNP & توليد ناخالص ملى & Non-elliptic initialism & Descriptive translation \\
\hline UNPD & UNPD & Non-elliptic initialism & Borrowing \\
\hline AIDS & ايدز & Non-elliptic initialism & Transcription \\
\hline SARS & سارس & Non-elliptic initialism & Transcription \\
\hline KGB & KGB & Non-elliptic initialism & Borrowing \\
\hline KGB & كا گ ب & Non-elliptic initialism & Transference \\
\hline NATO & ناتو & Non-elliptic initialism & Transliteration \\
\hline
\end{tabular}




\begin{tabular}{|c|c|c|c|}
\hline MTV & شبكه 》|م.تى.وى" & Non-elliptic initialism & Transcription \\
\hline GSP & GSP & Non-elliptic initialism & Borrowing \\
\hline FIR & اطلاعات پروازى منطقه & Non-elliptic initialism & Descriptive translation \\
\hline CNN & سى ان ان & Non-elliptic initialism & Transcription \\
\hline MTV & MTV & Non-elliptic initialism & Borrowing \\
\hline RIV/AIDS & " & Non-elliptic initialism & Transliteration \\
\hline GDP & توليد ناخالص ملى & Non-elliptic initialism & Descriptive translation \\
\hline $\mathrm{BBC}$ & $\mathrm{BBC}$ & Non-elliptic initialism & Borrowing \\
\hline USSR & شوروى & Non-elliptic initialism & Descriptive translation \\
\hline USSR & اتحاد جماهير شوروى & Non-elliptic initialism & Descriptive translation \\
\hline GSM & GSM & Non-elliptic initialism & Borrowing \\
\hline GPS & GPS & Non-elliptic initialism & Borrowing \\
\hline OECD & OECD & Non-elliptic initialism & Borrowing \\
\hline MCA & ام سى اى & Non-elliptic initialism & Transcription \\
\hline NHK & ان انج كى & Non-elliptic initialism & Transcription \\
\hline$A B C$ & اى بى سى & Non-elliptic initialism & Transcription \\
\hline NGO & سمن & Non-elliptic initialism & Transference \\
\hline NGO & سازمان غير دولتى & Non-elliptic initialism & Descriptive translation \\
\hline WTO & WTO & Non-elliptic initialism & Borrowing \\
\hline GCG & GCG & Non-elliptic initialism & Borrowing \\
\hline GCG & كروه مجازى غنا & Non-elliptic initialism & Descriptive translation \\
\hline UNESCO & يونسكو & Non-elliptic initialism & Transliteration \\
\hline NGO & سمن & Non-elliptic initialism & Transference \\
\hline UN & سازمان ملل & Non-elliptic initialism & Descriptive translation \\
\hline OWI & دفتر اطلاعات جنگ & Non-elliptic initialism & Descriptive translation \\
\hline OSS & ----- & Non-elliptic initialism & Omission \\
\hline VOA & صداى آمريكا & Non-elliptic initialism & Descriptive translation \\
\hline VOA & VOA & Non-elliptic initialism & Borrowing \\
\hline USIA & ----- & Non-elliptic initialism & Omission \\
\hline USIA & USIA & Non-elliptic initialism & Borrowing \\
\hline
\end{tabular}




\begin{tabular}{|c|c|c|c|}
\hline $\mathrm{ClA}$ & $\mathrm{ClA}$ & Non-elliptic initialism & Borrowing \\
\hline CSECE & CSECE & Non-elliptic initialism & Borrowing \\
\hline GDP & توليد ناخالص داخلى & Non-elliptic initialism & Descriptive translation \\
\hline SEAT & SEAT & Non-elliptic initialism & Borrowing \\
\hline CSCE & CSCE & Non-elliptic initialism & Borrowing \\
\hline CSCE & كنفرانس امنيت و همكارى & Non-elliptic initialism & Borrowing \\
\hline NATO & NATO & Non-elliptic initialism & Borrowing \\
\hline W3C & W3C & Alphabetism with numeral & Borrowing \\
\hline WIPO & WIPO & Non-elliptic initialism & Borrowing \\
\hline IBRD & بانك بينالملى ترميم و & Non-elliptic initialism & Descriptive translation \\
\hline GATT & كات & Non-elliptic initialism & Transliteration \\
\hline EEC & جامعه اقتصادى ارويا & Non-elliptic initialism & Descriptive translation \\
\hline ASEAN & انجمن ملل جنوب شرقى آسيا & Non-elliptic initialism & Descriptive translation \\
\hline IMO & سازمان بينالمللى دريايى & Non-elliptic initialism & Descriptive translation \\
\hline UNIDO & سازمان توسعه صنعتى ملل & Non-elliptic initialism & Descriptive translation \\
\hline BSE & BSE & Non-elliptic initialism & Borrowing \\
\hline ECOSOC & شوراى اقتصادى و اجتماعى & Non-elliptic initialism & Descriptive translation \\
\hline CFSP & CFSP & Non-elliptic initialism & Borrowing \\
\hline WTO & WTO & Non-elliptic initialism & Borrowing \\
\hline COPA & COPA & Non-elliptic initialism & Borrowing \\
\hline ETUC & ETUC & Non-elliptic initialism & Borrowing \\
\hline IBRD & بانك جهانى & Non-elliptic initialism & Descriptive translation \\
\hline DESA & 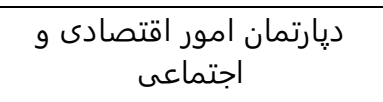 & Non-elliptic initialism & Descriptive translation \\
\hline DESA & DESA & Non-elliptic initialism & Borrowing \\
\hline UNMOVIC & UNMOVIC & Non-elliptic initialism & Borrowing \\
\hline PISA & PISA & Non-elliptic initialism & Borrowing \\
\hline TRAFFIC & TRAFFIC & Non-elliptic initialism & Borrowing \\
\hline UNIIMOG & UNIIMOG & Non-elliptic initialism & Borrowing \\
\hline
\end{tabular}




\begin{tabular}{|c|c|c|c|}
\hline UNBMIH & UNBMIH & Non-elliptic initialism & Borrowing \\
\hline CTBT & CTBT & Non-elliptic initialism & Borrowing \\
\hline NPT & NPT & Non-elliptic initialism & Borrowing \\
\hline IAEA & IAEA & Non-elliptic initialism & Borrowing \\
\hline CWC & معاهده منع جامع سلاحهاى & Non-elliptic initialism & Descriptive translation \\
\hline TPRB & بازنكرى سياست خارجى & Non-elliptic initialism & Descriptive translation \\
\hline WTO & سازمان تجارت جهانى & Non-elliptic initialism & Descriptive translation \\
\hline ESAF & ESAF & Non-elliptic initialism & Borrowing \\
\hline ECU & ECU & Non-elliptic initialism & Borrowing \\
\hline CFC & CFC & Non-elliptic initialism & Borrowing \\
\hline UNEP & UNEP & Non-elliptic initialism & Borrowing \\
\hline PCC1 & PCC1 & Alphabetism with numeral & Borrowing \\
\hline ICTY & ICTY & Non-elliptic initialism & Borrowing \\
\hline ICTR & ICTR & Non-elliptic initialism & Borrowing \\
\hline
\end{tabular}

Data collected from news texts:

\begin{tabular}{|c|c|c|c|}
\hline Abbreviation & Persian equivalent & Type of abbreviation & Translation Strategy \\
\hline CAIR & شوراى روابط آمريكايى- & Non-elliptic initialism & Descriptive translation \\
\hline AFP & --- & Non-elliptic initialism & Omission \\
\hline LHR & فرودگاه هيترو لندن & Non-elliptic initialism & Descriptive translation \\
\hline IED & دستكاه انجارى بداهه & Non-elliptic initialism & Descriptive translation \\
\hline GOP & حزب جمهورىخواه & Non-elliptic initialism & Descriptive translation \\
\hline NATO & ------ & Non-elliptic initialism & Omission \\
\hline ICBM & موشك بالستيك قارهييما & Non-elliptic initialism & Descriptive translation \\
\hline SDF & نيروهاى دموكراتيك سوريه & Non-elliptic initialism & Descriptive translation \\
\hline $\mathrm{NE}$ & ----- & Non-elliptic initialism & Omission \\
\hline SPD & ----- & Non-elliptic initialism & Omission \\
\hline NPD & حزب دموكراتيك ملى & Non-elliptic initialism & Descriptive translation \\
\hline AUMF & 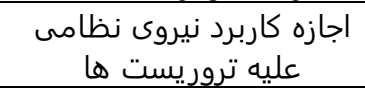 & Non-elliptic initialism & Descriptive translation \\
\hline NRA & انجمن ملى سلاح & Non-elliptic initialism & Descriptive translation \\
\hline $\mathrm{ECHR}$ & كنوانسيون ارويايى حقوق & Non-elliptic initialism & Descriptive translation \\
\hline CAATSA & 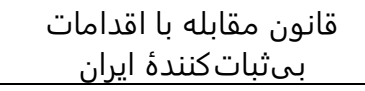 & Non-elliptic initialism & Descriptive translation \\
\hline $\mathrm{SACH}$ & ----- & Non-elliptic initialism & Omission \\
\hline INF & 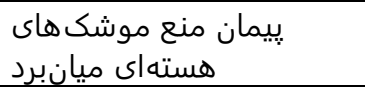 & Non-elliptic initialism & Descriptive translation \\
\hline ITV & ----- & Non-elliptic initialism & Omission \\
\hline FSKN & ------ & Non-elliptic initialism & Omission \\
\hline
\end{tabular}




\begin{tabular}{|c|c|c|c|}
\hline PLA & ارتش آزادىبخش خلق & Non-elliptic initialism & Descriptive translation \\
\hline USARPAC & ----- & Back-clipping & Omission \\
\hline IPO & ----- & Non-elliptic initialism & Omission \\
\hline MEP & عضو ِِارلمان ارويِا & Non-elliptic initialism & Descriptive translation \\
\hline AEB & ---- & Non-elliptic initialism & Omission \\
\hline$A P$ & اسوشيتد يرس & Non-elliptic initialism & Transcription \\
\hline AIQIS & ----- & Non-elliptic initialism & Omission \\
\hline NDS & رياست عمومى امنيت ملى & Non-elliptic initialism & Descriptive translation \\
\hline JASTA & جاستا & Non-elliptic initialism & Transference \\
\hline $\mathrm{CIA}$ & سيا & Non-elliptic initialism & Transcription \\
\hline NASSI & ----- & Non-elliptic initialism & Omission \\
\hline $\mathrm{FBI}$ & $\mathrm{FBI}$ & Non-elliptic initialism & Borrowing \\
\hline JASTA & قانون عدالت عليه حاميان & Non-elliptic initialism & Descriptive translation \\
\hline DNC & كميته ملى دموكرات & Non-elliptic initialism & Descriptive translation \\
\hline MI5 & ام آى 5 & Alphabetism with numeral & Transcription \\
\hline MI6 & ام آى 6 & Alphabetism with numeral & Transcription \\
\hline SIS & سازمان اطلاعات مخفى & Non-elliptic initialism & Descriptive translation \\
\hline $\mathrm{FBI}$ & اف بي آى & Non-elliptic initialism & Transcription \\
\hline FSB & سازمان امنيت فدرال روسيه & Non-elliptic initialism & Descriptive translation \\
\hline IOM & سازمان بينالمللى مهاجرت & Non-elliptic initialism & Descriptive translation \\
\hline CBS & سى بى اس & Non-elliptic initialism & Transcription \\
\hline EU & ----- & Non-elliptic initialism & Omission \\
\hline UAE & 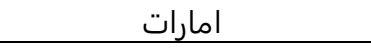 & Non-elliptic initialism & Descriptive translation \\
\hline MSNBC & ام اس ان بى سى & Non-elliptic initialism & Transcription \\
\hline NPT & ----- & Non-elliptic initialism & Omission \\
\hline SPA & مجمع عالى خلق كره شمالى & Non-elliptic initialism & Descriptive translation \\
\hline EAD & اجازه كار & Non-elliptic initialism & Descriptive translation \\
\hline BMP20 & بى ام يֶى 20 & $\begin{array}{l}\text { Alaphabetism with } \\
\text { numeral }\end{array}$ & Transcription \\
\hline IDF & ارتش اسرائيل & Non-elliptic initialism & Descriptive translation \\
\hline G-20 & جی-20 & Alphabetism with numeral & Transcription \\
\hline PJAK & 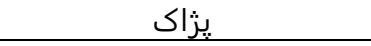 & Non-elliptic initialism & Transliteration \\
\hline USS & ----- & Non-elliptic initialism & Omission \\
\hline FYROM & جمهورى يوگوسلاوى سابق & Non-elliptic initialism & Descriptive translation \\
\hline EAD & ----- & Non-elliptic initialism & Omission \\
\hline PIA & 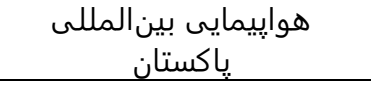 & Non-elliptic initialism & Descriptive translation \\
\hline IADS & سيستم دفاع هوايى يكيارجه & Non-elliptic initialism & Descriptive translation \\
\hline GSOMIA & ------ & Non-elliptic initialism & Omission \\
\hline RAF & نيروى هوايى سلطنتى & Non-elliptic initialism & Descriptive translation \\
\hline LBC & ال بى سى & Non-elliptic initialism & Transcription \\
\hline QRA & ---- & Non-elliptic initialism & Omission \\
\hline PIR & ----- & Non-elliptic initialism & Omission \\
\hline PKK & حزب كارگران كردستان & Non-elliptic initialism & Descriptive translation \\
\hline HOPE & ----- & $\begin{array}{l}\text { Semantically-relevant } \\
\text { acrostic }\end{array}$ & Omission \\
\hline MAKS & ماكس & Non-elliptic initialism & Transliteration \\
\hline VUB & ---- & Non-elliptic initialism & Omission \\
\hline DMZ & منطقه غير نظامى & Non-elliptic initialism & Descriptive translation \\
\hline IADS & ---- & Non-elliptic initialism & Omission \\
\hline DF-3A & DF-3A & Alphabetism with numeral & Borrowing \\
\hline
\end{tabular}




\begin{tabular}{|c|c|c|c|}
\hline DF-21 & DF-21 & Alphabetism with numeral & Borrowing \\
\hline AFP & خبرگزارى فرانسه & Non-elliptic initialism & Descriptive translation \\
\hline MSF & يزشكان بدون مرز & Non-elliptic initialism & Descriptive translation \\
\hline HRC & ----- & Non-elliptic initialism & Omission \\
\hline INSTEX & اينستكس & $\begin{array}{l}\text { Non-elliptic initialism \& } \\
\text { back-clipping }\end{array}$ & Transliteration \\
\hline DHS & ---- & Non-elliptic initialism & Omission \\
\hline $\mathrm{F}-35$ & اف-35 & Alphabetism with numeral & Transcription \\
\hline ICBM & ---- & Non-elliptic initialism & Omission \\
\hline S-400 & اس-400 & Alphabetism with numeral & Transcription \\
\hline $\mathrm{FBI}$ & ----- & Non-elliptic initialism & Omission \\
\hline IAEA & آزانس بينالمللى انرزى اتمى & Non-elliptic initialism & Descriptive translation \\
\hline SATMA & ساتما & Non-elliptic initialism & Transliteration \\
\hline STFI & ----- & Non-elliptic initialism & Omission \\
\hline NSC & شوراى امنيت ملى آمريكا & Non-elliptic initialism & Descriptive translation \\
\hline CFR & شوراى روابط خارجى & Non-elliptic initialism & Descriptive translation \\
\hline PPS & ---- & Non-elliptic initialism & Omission \\
\hline WTO & سازمان تجارت جهانى & Non-elliptic initialism & Descriptive translation \\
\hline RQ-4 & آركيو-4 & Alphabetism with numeral & Transcription \\
\hline USS & كشتى جنكى نيروى دريايى & Non-elliptic initialism & Descriptive translation \\
\hline YPG & ----- & Non-elliptic initialism & Omission \\
\hline SPV & ساز و كار و يزه بازركانى و & Non-elliptic initialism & Descriptive translation \\
\hline UNHQ & مقر سازمان ملل متحد & Non-elliptic initialism & Descriptive translation \\
\hline KCNA & ---- & Non-elliptic initialism & Omission \\
\hline NDAA & NDAA & Non-elliptic initialism & Borrowing \\
\hline USMCA & توافق ايالات متحده-مكزيك- & Non-elliptic initialism & Descriptive translation \\
\hline BAMS-D & BAMS-D & Non-elliptic initialism & Borrowing \\
\hline TOC & جرم سازمانيافته & Non-elliptic initialism & Descriptive translation \\
\hline$M Q-4 C$ & ام كيو4-سى & Alphabetism with numeral & Transcription \\
\hline WTO & ---- & Non-elliptic initialism & Omission \\
\hline YPG & ى يّ گ & Non-elliptic initialism & Transference \\
\hline NATO & 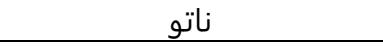 & Non-elliptic initialism & Transliteration \\
\hline S-300PT & اس-300 يֶى تى & Alphabetism with numeral & Transcription \\
\hline S-300PT & اس-300 & Alphabetism with numeral & Transcription \\
\hline TEL & TEL & Non-elliptic initialism & Borrowing \\
\hline SNCF & راه آهن ملى فرانسه & Non-elliptic initialism & Descriptive translation \\
\hline TGV & حملونقل ريلى بين شهرى & Non-elliptic initialism & Descriptive translation \\
\hline ASEAN & آ سه آن & Non-elliptic initialism & Transliteration \\
\hline CFSP & سياست خارجى اتحاديه ارويا & Non-elliptic initialism & Descriptive translation \\
\hline UNAMA & يوناما & Non-elliptic initialism & Transference \\
\hline DOD & وازارت دفاع آمريكا & Non-elliptic initialism & Descriptive translation \\
\hline DW & دويجه وله & Non-elliptic initialism & Transliteration \\
\hline$R \& D$ & فعاليت هاى تحقيق و توسعه & Alphabetism with symbol & Descriptive translation \\
\hline CDU & حزب دمكرات مسيحى آلمان & Non-elliptic initialism & Descriptive translation \\
\hline SPD & حزب سوسيال دمكرات & Non-elliptic initialism & Descriptive translation \\
\hline SDF & ---- & Non-elliptic initialism & Omission \\
\hline DOD & ----- & Non-elliptic initialism & Omission \\
\hline NDAA & قانون اختيارات دفاعى ملى & Non-elliptic initialism & Descriptive translation \\
\hline INSTEX & INSTEX & Non-elliptic initialism & Borrowing \\
\hline JCPOA & برجام & Non-elliptic initialism & Transference \\
\hline
\end{tabular}




\begin{tabular}{|c|c|c|c|c|c|}
\hline $\mathrm{Dec}$ & دسامبر & \multicolumn{2}{|c|}{ Back-clipping } & Omission & \\
\hline NTC & دولت وفاق ملى ليبى & \multicolumn{2}{|c|}{ Elliptic initialism } & Descriptive translation & \\
\hline NPT & ان يֶى تى & \multicolumn{2}{|c|}{ Non-elliptic initialism } & Transcription & \\
\hline NSA & آزانس امنيت ملى آمريكا & \multicolumn{2}{|c|}{ Non-elliptic initialism } & Descriptive translation & \\
\hline AQIS & القائده در شبه قاره هند & \multicolumn{2}{|c|}{ Non-elliptic initialism } & Descriptive translation & \\
\hline ABM & يِيمان موشك هاى ضد & \multicolumn{2}{|c|}{ Non-elliptic initialism } & Descriptive translation & \\
\hline CAATSA & ----- & \multicolumn{2}{|c|}{ Non-elliptic initialism } & Omission & \\
\hline START & استارت & \multicolumn{2}{|c|}{ Non-elliptic initialism } & Transliteration & \\
\hline $\mathrm{COE}$ & --- & \multicolumn{2}{|c|}{ Non-elliptic initialism } & Omission & \\
\hline CDC & مركز كنترل و ييشكيرى & Nor & Illiptic initialism & Descriptive translation & \\
\hline CAA & اعتراضات به اصلاحيه قانون & Nor & Illiptic initialism & Descriptive translation & \\
\hline NRC & لايحه شهروندى & Nor & Iliptic initialism & Descriptive translation & \\
\hline MSF & ---- & Nor & Iliptic initialism & Omission & \\
\hline TAAD & تاد & Nor & Iliptic initialism & Transliteration & \\
\hline BJP & حزب حاكم بهاراتيا جاناتا & Nor & Iliptic initialism & Descriptive translation & \\
\hline HUD & وزارت مسكن و توسعه & Nor & Iliptic initialism & Descriptive translation & \\
\hline UAV & يهياد & Nor & Iliptic initialism & Transference & \\
\hline SNP & حزب ملى اسكاتلند & Nor & Iliptic initialism & Descriptive translation & \\
\hline KCNA & "كِى. سى. إن. إى" & Nor & Iliptic initialism & Transcription & \\
\hline MP & نماينده مجلس & Nor & Iliptic initialism & Descriptive translation & \\
\hline$A B C$ & اى بى سى & Nor & Iliptic initialism & Transcription & \\
\hline UN & سازمان ملل & Nor & Illiptic initialism & Descriptive translation & \\
\hline UNSMIL & ماموريت يشتيبانى سازمان ملحد از ليبى & Nor & Iliptic initialism & Descriptive translation & \\
\hline GNA & ----- & Nor & Iliptic initialism & Omission & \\
\hline OFAC & دفتر كنترل دارايىهاى & Nor & Iliptic initialism & Descriptive translation & \\
\hline USDT & وزارت خزانه دارى آمريكا & Nor & Iliptic initialism & Descriptive translation & \\
\hline NATO & ----- & Nor & Iliptic initialism & Omission & \\
\hline E.O. & فرمان اجرايى & Nor & Iliptic initialism & Descriptive translation & \\
\hline IRGC & سيّاه يِاسداران & Nor & Illiptic initialism & Descriptive translation & \\
\hline START & معاهده كاهش سلاحهاى & $\begin{array}{l}\text { Sen } \\
\text { acrc }\end{array}$ & $\begin{array}{l}\text { tically-relevant } \\
\text { ic }\end{array}$ & Descriptive translation & \\
\hline OPEC & كشورهاى صاركنندهى نفت & Nor & Illiptic initialism & Descriptive translation & \\
\hline IDA & انجمن بينالمللى توسعه & Nor & Illiptic initialism & Descriptive translation & \\
\hline OAU & سازمان وحدت آفريقا & Nor & Illiptic initialism & Descriptive translation & \\
\hline ASW & 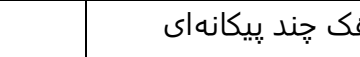 & & Non-elliptic in & Descriptive tran & \\
\hline MIRVs & 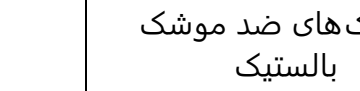 & & Non-elliptic in & Descriptive tran & tion \\
\hline$A B M$ & ات ضد ماهوارهاى & تسل! & Non-elliptic in & Descriptive tran & tion \\
\hline
\end{tabular}




\begin{tabular}{|c|c|c|c|}
\hline SPIEF & نشست بين الملى اقتصادى & Non-elliptic initialism & Descriptive translation \\
\hline $\mathrm{AOC}$ & ----- & Non-elliptic initialism & Omission \\
\hline DNC & كميته ملى دموكراتيك & Non-elliptic initialism & Descriptive translation \\
\hline MAS & جنبش براى سوسياليسم & Non-elliptic initialism & Descriptive translation \\
\hline CNN & سى ان ان & Non-elliptic initialism & Transcription \\
\hline $\mathrm{OMB}$ & مديريت بودجه كاخ سفيد & Non-elliptic initialism & Descriptive translation \\
\hline ECB & بانك مركزى ارويا & Non-elliptic initialism & Descriptive translation \\
\hline DFID & اداره توسعه بينالمللى & Non-elliptic initialism & Descriptive translation \\
\hline
\end{tabular}

